Published in Water Air and Soil Pollution v. 153, pp. 195-203 (2004) @ Kluwer Academic Publishers.

\title{
EVALUATION OF TRACE METAL FLUXES TO SOILS IN THE HINTERLAND OF PORTO MARGHERA, INDUSTRIAL AREA: COMPARISONS WITH DIRECT MEASUREMENTS IN THE LAGOON OF VENICE
}

\author{
ROBERTO SCAZZOLA ${ }^{1}$, GABRIELE MATTEUCCI ${ }^{2 *}$, STEFANO \\ GUERZONI $^{3}$, ELISA CHIAMENTI ${ }^{1}$, PAOLO ROSSINI $^{2}$, \\ EMANUELA MOLINAROLI ${ }^{4}$
}

${ }^{1}$ ARPAV - Dipartimento Provinciale Venezia, Via Lissa 6, 30175 Venezia Mestre, Italy

${ }^{2}$ CSA Ricerche, Via Al Torrente 22, 47900 Rimini, Italy

${ }^{3}$ CNR - ISMAR, Riva VII Martiri 1364/A, 30122 Venezia, Italy

${ }^{4}$ Università Ca' Foscari, Dipartimento di Scienze Ambientali, Dorsoduro 2137, 30123 Venezia, Italy

(*author for correspondence, e-mail: gmatteucci@csaricerche.com)

\begin{abstract}
Trace metal (As, Cd, Cr, $\mathrm{Ni}, \mathrm{Hg}, \mathrm{Pb}$ ) concentrations in soil samples collected around the Porto Marghera (Italy) industrial district $(2-40 \mathrm{~km})$ near the city of Venice were compared with direct
\end{abstract}


measurements of atmospheric deposition measured at comparable distances from the same source. Concentrations of $\mathrm{Cd}$ and $\mathrm{Pb}$ in soils decreased exponentially with increasing distance from the source; less clear signals were detected for As, $\mathrm{Cr}$ and Ni. Significant differences were found among the soils, which were partially resolved when applying normalisation to their clay contents. Preliminary comparisons of fluxes of $\mathrm{Cd}$ and $\mathrm{Pb}$ derived from soil with direct deposition measurements show increasing values with longer integration times. Annual $\mathrm{Cd}$ and $\mathrm{Pb}$ flux values of one year of direct deposition were 5 to 10 times lower than mean annual fluxes derived from soils, integrating 50 to 100 years. Values range from $\sim 0.1-0.4$ to 1-2 $\mathrm{mg} \mathrm{m}^{-2} \mathrm{yr}^{-1}$ for $\mathrm{Cd}$, and from 3-18 to $50-100 \mathrm{mg} \mathrm{m}^{-2} \mathrm{yr}^{-1}$ for $\mathrm{Pb}$. These results fit information on "historical" emission trends as recorded in sediments of the lagoon.

Keywords: atmospheric deposition, industrial fall-out, Lagoon of Venice, soil pollution, trace metals.

\section{Introduction}

Although several recent studies have revealed elevated concentrations of pollutants in the Lagoon of Venice (Di Domenico et al., 1997; Di Domenico et al., 1998; Wenning et al., 2000), relatively little is understood about heavy metal conditions in inland coastal areas. 
Within the framework of a monitoring program devoted to soil pollution in the vicinity of the Porto Marghera industrial district, located on the border of the Lagoon of Venice, 42 soil samples were collected in 1998 (Della Sala et al., 1999) and interim data on atmospheric fall-out of trace metals were provided by collecting bulk depositions from four stations inside the Lagoon of Venice (Fig. 1; Guerzoni et al., 1995).

Preliminary results of soil and atmospheric deposition studies have already been presented, showing clear decreases in some metals in soil with distance, connected with a main source in the industrial area (Di Domenico et al., 1998). Similar results come from bulk deposition sampling, which showed marked trends in atmospheric fluxes of pollutants with distance from Porto Marghera (Guerzoni et al., 1995; Rossini et al., 2001a).

The main aim of the present project was to assess comparisons between two projects related to heavy metals in soils and atmospheric deposition of metals. In addition, further evaluation of pedological parameters was carried out (Alloway, 1995; Baize, 1997), in order to identify better soils in an undisturbed state that have most likely been subjected to the industrial fall-out of the last 50-100 years.

\section{Experimental}

Of the 42 sites sampled, 34 were downgradient, i.e., at increasing distances from the central industrial zone, 5 were from the urban area 
of the city of Mestre (on the mainland opposite Venice) and 4 were in agricultural areas (Torre di Mosto, Staffolo). The background sites were chosen in areas far from possible local industrial sources and in good environmental condition (Giunta Regionale del Veneto, 1998). Four of the 42 sampling locations had not been plowed or significantly disturbed for several years (according to their pedological characteristics).

Atmospheric total deposition was collected by means of a bulk sampler (Mosello et al., 1988), composed of a polyethylene bottle with a polyethylene funnel (surface area $=0.065 \mathrm{~m}^{2}$ ) placed inside a PVC container. A total of 44 monthly deposition bulk samples was collected at one site near an industrial area (Dogaletto), one site in the city of Venice, and two sites in the southern and northern ends of the Lagoon (Rossini et al., 2001a). Sampling was carried out following protocols adopted by the WMO (World Meteorological Organization), of which the CNR-ISMAR Institute is a scientific consultant (WMO/UNEP-MAP, 1998).

Soil physical characteristics and heavy metals (As, $\mathrm{Cd}, \mathrm{Cr}, \mathrm{Ni}, \mathrm{Pb}$ ) were quantified by the laboratory of the ARPAV Centro Agroambientale of Castelfranco Veneto (Italy). Standard methods established by the Italian Ministry of Agriculture (Ministero delle Risorse Agricole, Alimentari e Forestali, 1994) were followed for soil characterization determinations of grain size, organic matter, cation exchange capacity, $\mathrm{pH}$ and carbonates. Heavy metals were determined 
after acid sequence digestion of matrix aliquots and by atomic absorption spectroscopy.

Bulk deposition samples were filtered through $0.4-\mu \mathrm{m}$ diameter Nuclepore $^{\odot}$ polycarbonate pre-weighed filters. Filtering was done with a Millipore ${ }^{\odot}$ Sterifil unit, equipped with a pre-filter on the cover, to avoid contamination with ambient air. Sampling blanks were collected by washing the polyethylene funnel of the sampler with 500 $\mathrm{mL}$ of Milli- $\mathrm{Q}^{\mathrm{TM}}$ water (DDW), and laboratory blanks were also produced with DDW. Dissolved and particulate metal concentrations were determined by analysing filtered and residual fractions. After dissolution in an acidic mixture, the insoluble fraction was digested in Teflon bottles in a microwave digestion unit. Soluble and insoluble fractions were analysed for trace elements $(\mathrm{Cr}, \mathrm{Zn}, \mathrm{Pb}, \mathrm{Cd}, \mathrm{As})$ by AAS and ICP mass spectrometry. All manipulations were conducted in a clean room equipped with a laminar flow bench. Extraction, clean-up and analytical procedures are extensively described in Rossini et al., 2001b.

Figure 1. Location of soil and atmospheric deposition sampling sites. $(\mathrm{B}=$ Background $\sim 40 \mathrm{~km} ; \mathrm{U}=\mathrm{Urban}<5 \mathrm{~km} ; \mathrm{T} 1, \mathrm{~T} 2, \mathrm{~T} 3=$ Transects $)$. 


\section{Results and Discussion}

Some calculations were applied to soil data, in order to compare better soil and atmospheric deposition. The distances of the sampling sites were calculated from the hypothetical emission barycentre on the main point sources of atmospheric emissions from the Porto Marghera industrial area. Taking into account many studies stressing the importance of pedological development and soil rehashing for correct assessment of analytical soil data (Alloway, 1995; Kabata-Pendias and Pendias, 1984), we subdivided soil samples into homogeneous classes and applied normalisation on the basis of their clay contents. The complete set of soil samples was divided into undisturbed, agricultural and urban soils, all close to Porto Marghera ( 4-5 Km), and compared with more distant background soils (Table 1).

Considerable differences in total $\mathrm{Cd}$ and $\mathrm{Pb}$ contents were detected between undisturbed and cultivated soils near Porto Marghera $(<4$ $\mathrm{km})$, with values 1-2 times higher in undisturbed soils. No differences in total contents of $\mathrm{Cr}, \mathrm{Ni}$ were seen, but the total As content in undisturbed soil was lower than in cultivated soil. Urban soil is enriched in $\mathrm{Pb}$, and remote soils have the lowest $\mathrm{Cd}, \mathrm{Pb}$ and $\mathrm{As}$ and the highest $\mathrm{Cr}$ and $\mathrm{Ni}$.

Very interesting comparisons came from the clay-normalised data, in which differences between undisturbed and cultivated soils near the industrial area were completely reduced for $\mathrm{Cd}$, and partially for $\mathrm{Pb}$. This was not the case for $\mathrm{Cr}$ and $\mathrm{Ni}$, in which the normalisation 
increased the differences, whereas As seemed unaffected. Normalisation in urban soils enhanced $\mathrm{Pb}$ enrichment. Values in remote soils became the lowest for all metals after clay normalisation. The behaviour of $\mathrm{Cd}$ and $\mathrm{Pb}$ with normalisation suggested that the industrial (and perhaps also urban) pollution signals were evident at distances of $<5 \mathrm{~km}$, and is mainly transported by fine-grained aerosols, with some possible contribution from traffic lead, more independent of the transport carrier (i.e. coarser grain size).

$\mathrm{Cr}$ and $\mathrm{Ni}$ are geochemically important, and probably correlated more closely with the mineralogical phases of coarser grain sizes, so that normalisation increased differences instead of smoothing them.

As is unaffected by clay normalisation and presents regional geochemical variability in different areas $(\mathrm{Bkg}=\sim 10 \mathrm{mg} / \mathrm{kg}$ in the north, and 25 in the south as reported by Scazzola et al., 2002, and 510 in lagoon sediments, according to the Water Management Authority of Venice, Magistrato alle Acque di Venezia, 1999). This fact, in connection with possible multiple sources (i.e., industry, glassworking, agriculture), made the behaviour of this metal difficult to explain.

\section{TABLE I}

Total and clay-normalised concentrations of $\mathrm{As}, \mathrm{Cd}, \mathrm{Cr}, \mathrm{Ni}$ and $\mathrm{Pb}$ in soil samples, subdivided into homogeneous classes. 
The normalisation procedure highlighted the strong industrial signals for $\mathrm{Cd}$ and $\mathrm{Pb}$. Focusing on one of the three downwind transects (T1), the exponential decay $\left(y=y 0+a e^{-b x} ;\right.$ where $y=$ element concentration, $\mathrm{y} 0=$ background element concentration and $\mathrm{x}=$ distance) of $\mathrm{Cd}$ and $\mathrm{Pb}$ with increasing distance from the industrial district was revealed (Figure 2). Other metals (As, Cr, Ni) did not follow the same regular patterns of $\mathrm{Cd}$ and $\mathrm{Pb}$, suggesting different multiple origins. In particular, concentrations of $\mathrm{Cd}$ and $\mathrm{Pb}$ collected downgradient from the central industrial zone were greater than background levels at close distances; beyond about 4-5 km, concentrations fell to background levels (Della Sala et al., 1999). These data were normalized by clay contents in soil samples and are plotted as total and normalized heavy metal concentrations (Figure 2).

Figure 2. Plot of concentrations $(\mathrm{mg} / \mathrm{kg})$ of total $\mathrm{Cd}$ and $\mathrm{Pb}(\mathrm{A}, \mathrm{C})$ and normalized $\mathrm{Cd}$ and $\mathrm{Pb}(\mathrm{B}, \mathrm{D})$ in soil samples of transect 1 (T1) with distance (m) from Porto Marghera industrial zone. Line represents curve fit (B - $r=0.66 ; \mathrm{D}-\mathrm{r}=0.52)$.

For quantitative comparisons of fluxes, soil concentrations were converted into fluxes, with the equation: 


$$
\text { flux }=\left(\mathrm{C}_{\mathrm{i}}-\mathrm{C}_{\mathrm{bkg}}\right) * \delta * \mathrm{z} / \mathrm{t}
$$

where $\mathrm{C}_{\mathrm{i}}=$ sample concentration value, $\mathrm{C}_{\mathrm{bkg}}=$ background concentration value, $\delta=$ bulk density, $\mathrm{z}=$ sample thickness and $\mathrm{t}=$ time interval.

For the sample concentration $(\mathrm{Ci})$ it was considered the mean values of undisturbed sites and for the time interval it was considered that the sampled layer $(15 \mathrm{~cm})$ represents the last $50-100$ years. This is reasonable, according to the pedogenetic structure, which shows no signs of disturbance, and the historical development of the industrial district (built in the 1920s).

These comparison were made for $\mathrm{Cd}$ and $\mathrm{Pb}$ by calculating the "excess" metal flux using background levels for the two metals derived from two different data sets. One was deduced from the profiles of two soil samples in which deeper pedological horizons were analysed separately. The other was the recent assessment of heavy metal background values in the inland coastal area of Venice (Scazzola et al., 2002). The values used were $0.4 \mathrm{mg} / \mathrm{kg}$ and $30 \mathrm{mg} / \mathrm{kg}$ for $\mathrm{Cd}$ and $\mathrm{Pb}$, respectively.

TABLE II

Annual flux of $\mathrm{Cd}$ and $\mathrm{Pb}\left(\mathrm{mg} \mathrm{m}^{-2}\right)$ derived from soils and measured in atmospheric deposition. 
Comparisons showed that "excess" fluxes of $\mathrm{Cd}$ and $\mathrm{Pb}$, estimated from concentrations of trace metals in undisturbed soils minus background, were 5 to 10 times higher than recent measurements of atmospheric deposition. Annual "excess" Cd fluxes, as integrated for 50-100 years in soil, were $1-2 \mathrm{mg} \mathrm{m}^{-2} \mathrm{yr}^{-1}$, whereas measurements in the period 1998-1999 gave flux values of 0.1-0.4 $\mathrm{mg} \mathrm{m}^{-2} \mathrm{yr}^{-1}$. The figures for $\mathrm{Pb}$ were $50-100$ and $3-18 \mathrm{mg} \mathrm{m}^{-2} \mathrm{yr}^{-1}$ for soil and atmosphere respectively. These results fit information on "historical" emission trends as recorded in sediments of the lagoon (Cochran et al., 1998): emissions started in the 1920s-1930s, peaked in the 1960s1980s, and are now declining, due to partial decline of industry, together with new national legislation on air emissions (D.P.R. 203/88 and others) and related abatement systems.

\section{Conclusions}

- Concentrations of $\mathrm{Cd}$ and $\mathrm{Pb}$ in soils decrease esponentially with increasing distance from the Porto Marghera industrial zone, and in the nearest soils (e.g., at distances $<4 \mathrm{~km}$ from the petrochemical industry) there are differences between undisturbed and cultivated soils. As, $\mathrm{Cr}$ and $\mathrm{Ni}$ do not show clear trends with distance, nor do they present significant differences between undisturbed and cultivated soil, probably being more affected by geochemistry matrix. 
- Preliminary comparisons of fluxes of $\mathrm{Cd}$ and $\mathrm{Pb}$ in soil with direct deposition measurements show increasing values with integration time. Annual $\mathrm{Cd}$ and $\mathrm{Pb}$ flux values of one year of direct deposition were 5 to 10 times lower than mean annual fluxes derived from soils, integrating 50 to 100 years. Values range from 0.1-0.4 to $1-2 \mathrm{mg} \mathrm{m}^{-2} \mathrm{yr}^{-1}$ for $\mathrm{Cd}$, and from 3-18 to $50-100 \mathrm{mg} \mathrm{m}^{-}$ ${ }^{2} \mathrm{yr}^{-1}$ for $\mathrm{Pb}$. These differences are probably due to the historical atmospheric emission trends of the area.

\section{Acknowledgements}

Ms Gabriel Walton revised the English text. This is contribution no.xxxx of the ISMAR Istituto per la Geologia Marina-CNR, Bologna (Italy).

\section{References}

Alloway, B.J.: 1995, Heavy metals in soils, 2nd ed., B.J. Alloway Ed., Blackie, Glasgow, 378 pp.

Baize, D.: 1997, Teneurs totales en éléments traces métalliques dans les sols, INRA Editions, Paris, 416 pp.

Cochran, J. K., Frignani, M., Salamanca, M., Bellucci, L.G. and Guerzoni, S.: 1998, 'Lead-210 as a tracer of atmospheric inputs 
of heavy metals in the northern Venice Lagoon', Mar. Chem. 62, $15-29$.

Della Sala, S., Scazzola, R., Terrabujo, C., Giandon, P., Wenning, R.J., Dodge, D., Luksemburg, W.J. and Weagraff, S.A.: 1999, 'Assessment of PCDD/Fs, PCBs, and Heavy Metals in Soil: a Measure of the Impact of the Industrial Zone of Porto Marghera on Inland Coastal Areas of Italy', Organohalogen Compounds 43, 137-141.

Di Domenico, A., Baldassarri, T., Ziemacki, L. AND Defelip, G.: 1997, 'Selected Carcinogenic Organic Microcontaminants and Heavy Metals in the Venice Lagoon', Organohalogen Compounds 34, 54-60.

Giunta Regionale del Veneto: 1998, 'Ambiente, il Veneto Verso il 2000', Regione del Veneto, Venezia.

Guerzoni, S., Molinaroli, E., Quarantotto, G. and Rampazzo, G.: 1995, 'Comparison of atmospheric and riverine fluxes of trace metals (Al, $\mathrm{Cd}, \mathrm{Cu}, \mathrm{Fe}, \mathrm{Ni}, \mathrm{Pb}$ ) in the Lagoon of Venice, Plinius, 14, 177-179.

Kabata-Pendias, A. and Pendias, H.: 1984, Trace Elements in Soils and Plants, CRC Press, Inc., Boca Raton, Florida U.S., 643 pp.

Magistrato alle Acque di Venezia: 1999, Attività per la Salvaguardia della Laguna di Venezia (Art. 3, L.798/1984) - Progetto Orizzonte 2023, Linea F, Consorzio Venezia Nuova, Venezia, Italy. 
Ministero delle Risorse Agricole, Alimentari e Forestali: 1994, Metodi Ufficiali di Analisi Chimica del Suolo, Ministero delle Risorse Agricole, Roma.

Mosello, R., Marchetto, A. and Tartari, G.A.: 1988, 'Bulk and Wet Atmospheric Deposition Chemistry at Pallanza (N. Italy)', Water Air Soil Pollut., 42, 137-145.

Rossini, P., De Lazzari, A., Guerzoni, S., Molinaroli, E., Rampazzo, G. and Zancanaro, A.: 2001a, 'Atmospheric Input of Organic Pollutants to the Venice Lagoon', Ann. Chim. (Rome), 91, 491501.

Rossini, P., Guerzoni, S., Rampazzo, G., Quarantotto, G., Garibbo, E., and Molinaroli, E.: 2001b, 'Atmospheric Deposition of Trace Metals in North Adriatic Sea', in E.M. Faranda, L. Guglielmo and G. Spezie (eds.), Mediterranean Ecosystem, Structures and Processes, Springer Verlag Italia, pp. 123-129.

Scazzola, R., Avezzù, S., Biancotto, R., Chiamenti, E., Chiozzotto, E., Gerotto, M., Palonta, M. and Roiter, S.: 2002, 'Determinazione del Livello di Fondo di Metalli Pesanti nei Suoli dell'Entroterra Veneziano', Proceedings of VII Congresso Nazionale di Chimica Ambientale, Venezia, Italy, 11-14 giugno 2002, pp. 104-105.

Wenning, R.J., Dodge, D., Peck, B., Shearer, K., Luksemburg, W., Della Sala, S. and Scazzola, R.: 2000, 'Screening- Level Ecological Risk Assessment of Polychlorinated Dibenzo-p- 
Dioxins and Dibenzofurans in Sediments and Aquatic Biota from the Venice Lagoon, Italy', Chemosphere, 40, 1179-1197.

WMO/UNEP-MAP: 1998, 'MED-POL Manual on Sampling and Analysis of Aerosols and Precipitation for Major Ions and Trace Elements', MAP Technical report series No. 123, UNEP, Athens, $166 \mathrm{pp}$. 
TRACE METALS IN SOIL AROUND PORTO MARGHERA

TABLE I

\begin{tabular}{|c|c|c|c|c|c|c|c|c|}
\hline & \multicolumn{2}{|c|}{$\begin{array}{c}\text { Untouched }(<4.0 \\
\mathbf{k m})\end{array}$} & \multicolumn{2}{|c|}{$\begin{array}{c}\text { Agricultural }(<4.0 \\
\mathbf{k m})\end{array}$} & \multicolumn{2}{|c|}{ Urban $(<\mathbf{5 k m})$} & \multicolumn{2}{|c|}{$\begin{array}{c}\text { Background ( 40 } \\
\text { km) }\end{array}$} \\
\hline & $\mathrm{mg} / \mathrm{kg}$ & mg clay/kg. & $\mathrm{mg} / \mathrm{kg}$ & mg clay/kg & $m g / k g$ & $\begin{array}{c}m g \\
\text { clay/kg }\end{array}$ & $\mathrm{mg} / \mathrm{kg}$ & $m g$ clay $/ k g$ \\
\hline $\mathrm{Cd}$ & $0.9 \pm 0.1$ & $3.4 \pm 1.5$ & $0.6 \pm 0.2$ & $3.5 \pm 1.6$ & $\begin{array}{c}0.7 \pm \\
0.2\end{array}$ & $3.4 \pm 1.0$ & $0.5 \pm 0.1$ & $1.2 \pm 0.1$ \\
\hline $\mathrm{Pb}$ & $53 . \pm 34$ & $175 \pm 41$ & $24 \pm 10$ & $127 \pm 27$ & $45 \pm 37$ & $236 \pm 203$ & $17 \pm 4$ & $42 \pm 9$ \\
\hline $\mathrm{Cr}$ & $17 \pm 6$ & $68 \pm 11$ & $18 \pm 5$ & $101 \pm 32$ & $23 \pm 8$ & $116 \pm 49$ & $26 \pm 10$ & $61 \pm 6$ \\
\hline $\mathrm{Ni}$ & $\begin{array}{c}19.83 \pm \\
6.03\end{array}$ & $74 \pm 13$ & $18 \pm 5$ & $103 \pm 32$ & $21 \pm 5$ & $104 \pm 32$ & $22 \pm 11$ & $50 \pm 13$ \\
\hline As & $12 \pm 8$ & $59 \pm 15$ & $17 \pm 5$ & $99 \pm 38$ & $19 \pm 12$ & $94 \pm 46$ & $8.4 \pm 5$ & $21 \pm 9$ \\
\hline
\end{tabular}

TABLE II

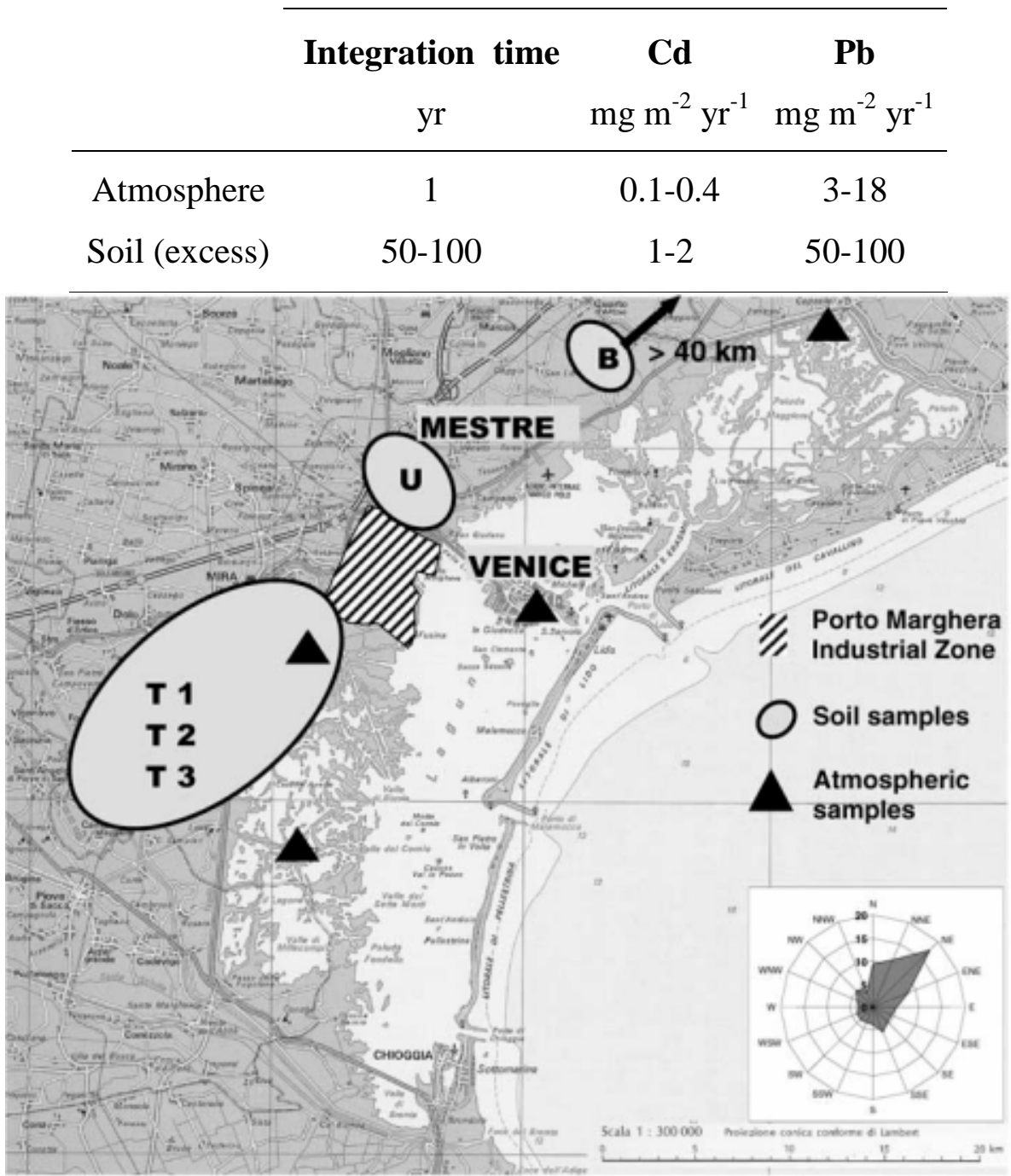

Fig. 1 
SCAZZOLA ET AL.
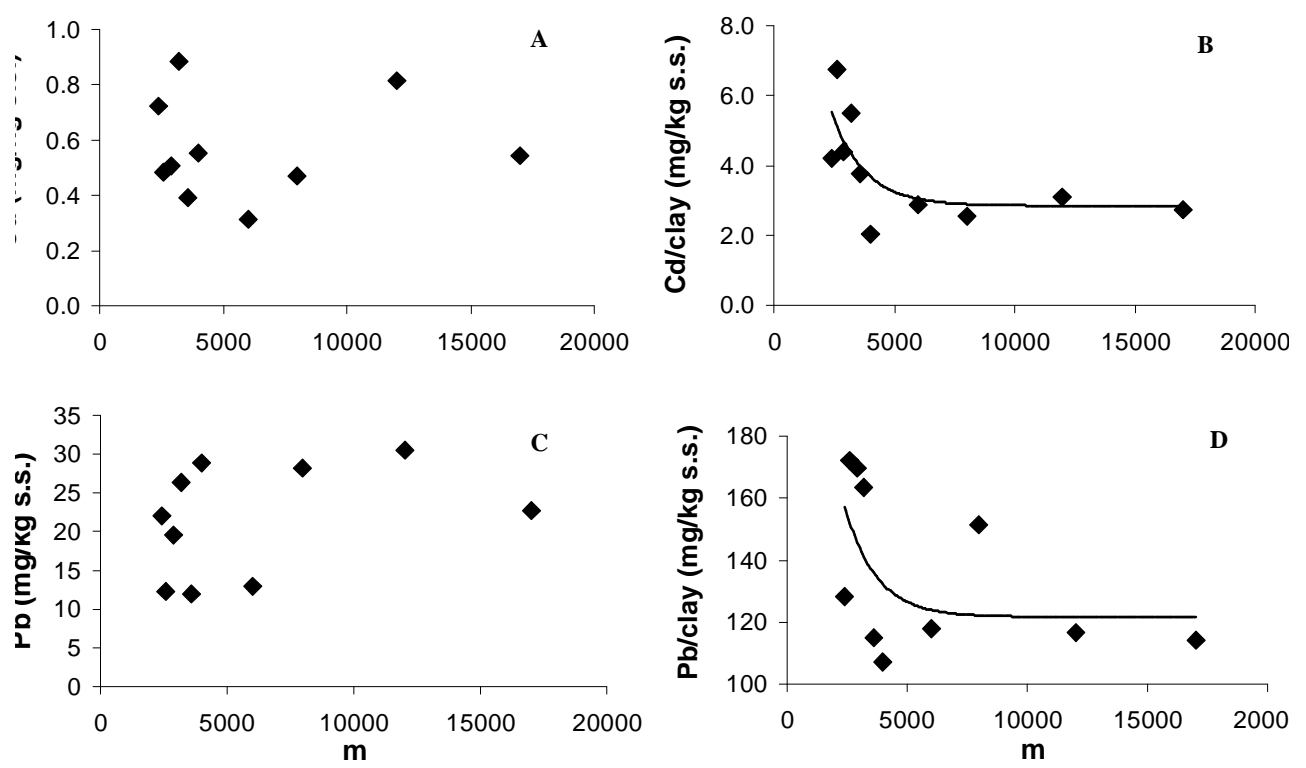

Fig. 2 